\title{
Inside the Body of a Green Apple Tree . Leon Forrest
}

\section{BILLIE HOLIDAY WAS SINGING "Full Moon and Empty}

Arms" and then Nathaniel Witherspoon was beginning to hear inside of Lady Day's sterling coloration, the dolorous wounds, the switchback humor and back into his mother's echoing voice, somersaulting throughout his heart. Madeline Witherspoon, Nathaniel's mother, was hanging up her back-porch laundry; his back was turned.

Then Nathaniel was knocked down onto his knees, where he and Maxwell Blackball Saltport had been shooting marbles in the 6x6-inch, spoon-dug ring-before the lightning cord and the showers-as he now saw amid the vivid rainbow, in the late-afternoon spring sky, inside the body of a huge green apple tree: the skeleton form of a woman, in a green silk gown; draped over by a flinging, sheer, golden cape.

Now the vision of the lady expanded suddenly into a flapping wingspread, and became one with the rainbow. There was a bejewelled band about her forehead. A necklace with a quarter-moon-shaped sapphire stone, shone at her throat. A golden crown appeared upon her head. A picnic basket of fruit trembled upon her right arm; and golden earrings, fashioned as vessels, glowed at her earlobes.

Then Nathaniel saw lodged inside the ribcage of the skeleton form, a protruding abdomen: with a full-moon-shaped, contorted, bloody, yolky-robed shell, encaged in a coiled net of pumpkin vines.

The substance of the rainbow crackled, bled into four rivers, vaulted out to a blood-red sea, where a host of luminous lobsters dipped and dived, then disintegrated into the images of statues, the faces of withering idols and mermaids; and the water grew grayish green. Nathaniel saw an eagle (with a greyhound in its mouth and a fish in the greyhound's mouth) go flying across a shawl-covered altar in a shower of changing colors; shifting forms into that of a rabbit, a wolf, and a dove ... Then a bear, a raven, and a whale....

Now Nathaniel was seeing the beautiful body of Lily-Beth Michaelson floating toward Aunt Bella-Lenore Boltwood's sewing machine, just past that wooden panel, where the seamstress placed wisps of her own silver, fallen hair into the crocheted bag each night... as if in her phantasy world of many colors she hoped to conjure the fiercely 
remembered, flowing, bounteous and beautiful tresses back into being upon her noble head, by first placing them in the bag, and there somehow they would be transformed. To ultimately return sealed to her skull by dawn through the magic of some tiny conjure woman who lived inside the bag, like one of the Teenie Weenies in the funny paper, who would then spin away inside the pot-bellied, pregnant-looking, rainbow-colored, sagging bag each night to produce the magical miracle. The spindle, upon Bella-Lenore's table, treasure spun with dress patterns of glorious fashions, for fitting fine royal frames. Bella's own diary to eternity, she called her self-conceived storehouse sheaf of form-flourishing, spirit-spinning resources, amid knitting needles, pins and threads of every color of the rainbow.

Now Lily-Beth seemed to float to her side for counsel.

Aunt Hattie Breedlove Wordlaw was saying of Bella-Lenore, as they all watched Lily-Beth's floating approach: "Bella makes a piece of cloth into a musical instrument and there the properly shaped and tuned body sings and hums inside of itself so that all who see the music of the clothing can never forget the Creator," as the magnetic, ebony-skinned Lily-Beth Michaelson (with a white gardenia in her hair and a heartshaped, emerald locket at her throat) came switching and shimmering down the streetcar line in the moonlight, 'designed' into one of BellaLenore Boltwood's patterned, original, golden creations of softest silk. Just at that moment, his father's camera-eye seemed to look through the whining body weave of the cloth-into Lily-Beth's musical heartNathaniel thought, as a boy, but now he knew how he felt; and placing his hand to his heart and looking across the street to the very top-floor window-where the curtain flung in the wind-and he merely thought he saw the outline of Lily-Beth's body; she often visited with his Aunt DuDora.

Bella-Lenore Boltwood made something magical happen to the material, quite different from the outlined pattern-magical in the sense too of character because she not only tailored the design of the pattern to the figure and cut of Lily-Beth's divine bodily form before her naked eyes, she also remade his third cousin in her own image.

But Uncle Ulysses Hampton said that "God Himself had designed Lily-Beth's body. Hovered over it for five days and six nights; added His personal touches; and He munched on an apple, for sustenance during His lunch breaks ... His work complete, God threw the pattern away, into the river of forgetfulness; then He fashioned the rest of the female 
race out of Adam's rib and fell asleep on the Seventh Day ... down by the riverside." Uncle Ulysses recited Paul Laurence Dunbar's "Angelina Johnson"; then he fell asleep. Nathaniel's mother had made the screen door of the porch slam as she went inside. Nathaniel thought that he would always have to remember that Lily-Beth was his third cousin.

Now Nathaniel stammered aloud to Blackball about the vision he saw inside the body of a green apple tree.

Maxwell Blackball Saltport backed off startled; with his hand to his mouth, he contemplated his retaliation. He wore a pair of dark brown trousers given to him by Miss Eliza Booker's 5'3" Filipino butler. The trousers were too large in the waist and he held them up with a frayed clothesline; knotted to a clothespin, that served as a belt buckle. A pair of dark glasses, slightly cracked at the edges and given to him by Regal Pettibone, covered his eyes. They were tilted on the bridge of his prominent nose to affect the appearance of General Douglas MacArthur. The tip of his Army cunt-cap, a la Montgomery was cocked gingerly upon his head. Blackball's tattered and hole-ridden, off-white gym shoes were laced up with orange strings for the left shoe and green strings for the right shoe. His shirt was a dime-store version of the Brooklyn Dodgers' travelling uniform top; with Jackie sprawled on the back in bold red, white and blue. Robinson's number 42 dominated the Blackball's back.

Down on both knees, with Uncle Ulysses' binoculars capped over his eyes, the stunned Nathaniel could not solely focus upon Blackball's words, spoken now with great seriousness and authority.

“... Sounds more like a witch; if she's riding your backbone you oughta do like my Momma says anybody with an eyedropper of common sense-ditch her; but stone freeze first.

"See, Natty-Batty, them witches takes off all their skin every nightthat's how come your Miss Lady didn't hardly have on no closes; justa tissue-paper cape; see-through gown; No drawers. ...

"Hangs the cape of her skin on a nail, off the wall; then goes out devilment-making, flying, cavorting, hovering over bodies, like a veil swooping darkness about a wicked widow woman's face. How come you can't see the pure body of them witches? Pitch your eyes to the back of your skullbone with reverse English; then you see skeleton's brothy blood ... keep going back; you'll see skin, if you got 20/10 vision."

Still in a state of wonderment at the transformation of the sky, in his mind's eye, Nathaniel only answered, "That's what your mother told you to say... Not what you know you ought to say." 
Blackball screeched, "Don't let your evil tongue convict your mouth to rowdiness," and now drawing a dare line in the earth, with the sock-exposed toe of his raggedy gym shoe, then jerking up his drooping trousers and cocking his dukes for immediate, though mock warfare, and tuning up a blue streak of purple-patched curses into an Indian War Cry, deploying the palm of his right hand as a top hat over a mock trumpet to recreate a war chant; finally calling Nathaniel back from his vision and his musing.

"I can't let you do that to my vision, even if I don't understand its comings and goings, myself," Nathaniel grimaced-standing pat on freeze like a soldier before the flag unfurling in the Heavens.

"See, Nathaniel, how that old C. C. riding witch's seesawing your mind down to sawdust. Overloading your unnatural circuits, BattyNatty. What you got to do is glide down her chimney. Pepper Tabasco sauce over that see-through skin hanging down from the nail, off the wall, like a mourning veil. Don't miss a spot, Spoons. Don't look more foolish than you are by nature.

"Hell, if you can see a woman in a rainbow you oughta be able to see a slip of silkworm skin, drooped over a nail off the wall, in the moonlight."

"Maxwell, next you'll tell me that witch's skin is drooping like the scrapple from the apple."

"... Beyond a doubt of the shadow's shade," he said in his mock radio-announcer's voice.

"Blackball, where have you lost the frog in your throat? You tadpole, you sound like an alto passing for a tenor."

"Don't get froggy, Spoons. Why I even seen you pin the tail on the donkey, blindfolded clean in the dark ... Your little old yallar fingers had glowworm eyes flashlighting through them (like they was tapping out time on them rose-heart beads) over at your shortening-bread's Halloween party, three years ago ... Your sight ain't commencing to backfire on you yet, just 'cause you still a demon jackass for Beatrice Treadwell's tail."

Yes, thought Nathaniel, but that was before Beatrice and I went into the back room, where no eyes were focussed to see, nor tongues to wag, and played spin-the-bottle with an emptied fifth of Mister Treadwell's Old Forester; and I 'won' Beatrice and we slow-danced jelly-belly tight to "Nadine" grinding away on the phonograph player in the front room. I wore a Sinbad-the-Sailor outfit ... (Before my mother's vanity table - and from out of her cosmetic bag-I 
had remade my face and features, with her Pan-Cake makeup and eyebrow pencil, and rouge to look poker-faced like the Brown Bomber, and stunningly handsome, cruel and utterly cool, like the pictures I had seen of Valentino, at the Joe Louis Theatre)... Beatrice was dressed as a Gypsy woman, in a rainbow-colored head-rag, and a fortune-telling 250 Watt light bulb, in her right hand, which contained a miniature jack-o'-lantern inside; Bea wore crimson lipstick, and streaks of fire like red rouge, that seemed burned through her nut-brown cheeks to match the flames in my loins; in her recently pierced ears dangled costume gold earrings. Her deep-sea-blue shirt-dappled by scores of butterfly shapes-seemed as soft as a bed sheet; she wore the sheerest kind of white, see-through blouse, so that her bra cups took over the blouse and seemed to cup forth, as if in offering. And then we kissed; and Beatrice placed the tip of her wonderful and wicked tongue on the very (hot) spot where Father O'Keefe had placed the First Holy Communion host, the week before. I felt my eyes bulge to the back of my head. Then I knew I was changed forever. I snatched the string to the ceiling light. The room turned blue black. With Bea in my trembling arms, I thought of what that cowboy had said to his lady in the movie, and just as I started to repeat ... "I could find you in the dark," Beatrice suddenly jumped back from my arms, yanked the string; and in the hot light she cried out in a mocking voice, with a pointing, wagging index finger: "I'm wise to the rise in your Levis."

Just then Blackball said, "See that part about hot, red leaping lobsters steady stirring at what you oughta do....

"Now just pepper-douse that skin ... souse it ... like you painting the town red," he instructed with great solemnity and the gingerly knowing quality of a ceremonial-orchestrating high priest-both hands raised aloft and his right hand acting as a magical saving wand of direction, censure and guidance. Nathaniel suddenly turned to see if Blackball saw some high-steppers in the distance, practicing for a parade, hightailing it on down the Stroll.

"And Blackball, just how will all this erase that sky in my mind? Not like the blackboard at school; and not what you think I said I saw, but what I know I saw 'fore I ever thought about hipping your seesaw mind, Mister Hindsight.

"And ... furthermore... Maxwell Blackball Saltport, what makes you think I want to get rid of my vision-for your ass-backwards view-just 'cause I can find a jackass' butt on a map in the darkblindfolded?"

"Spoony-Moony, that ain't the only ass you can find in the dark ... But you can't handle what I'm putting down. Listen up to what I'm laying 
down, skin-to-kin. First off that witch'll sit her jack-o'-lantern down on her vanity table; then place her broom in the corner, when she returns ... Tries to slip back into that old natural, nutting-on-down skin, real quick like she's slick with every season of saucy savvy; she'll howl, fry, weep, leap like she is being barbecued alive on the grill ... Can't get off for leapfrogging, hopscotching on-but she got to go through the motions or vanish trying."

"Vanish! But how am I to see her in the first place? Whose doing the anointing, you, or the Holy Ghost?"

"Cause of the turpentine and tar she bathes in makes her seeable to see-through eyes like yours... 'Sides, don't you understand nothing about them personable womenly days? That's when they change their ways. Change their bloodstreams." Then with great ceremony of gesture and confidentiality of a whispering voice through the apple tree, at midnight, but absolutely avoiding all eye contact: "On them days she uses a vanishing-cream rag for the dousing."

"Dousing? You mean," Nathaniel whispered. Then: "Oh-now I see. But you've changed the subject, Mister Blackball Warlock Saltport," Nathaniel said, suppressing a howl of knowing laughter.

“... Hear her steady now pleading, Nattie: 'Now skin don't you know me, your momma-and-poppa, your body and soul, you the flesh, the long suit of my pattern; I ain't setting for no fitting; so now reconnect to my dangling, disconnected invisible bones; be my skin again, soul of my stew-cold broth.' But when she says broth, she really mean-Blood. Then that'll be your Day-One Signal, Mister Spoons.

"Meanwhile she's hopping and leaping about like them Indians doing a triple-dutch war dance, getting ready for Hopalong Cassidy-without the rope-against the mean old cavalry, or like somebody sat firecrackers underneath the toe-jammed soles of some of them little old hot-tailed gals skipping rope double-dutch ... Already got the Saint Vitus dance switching in the panting-party-panties-'cause of their red-hot poontang natures coming down on them, eight to the bar...."

Then Blackball commenced to imitate both images, ending it all with an almighty leapfrog across the line he had dug in the groundcounting off deadheads while in flight, with five, I told you so Wau-Wau swooping sounds-as if nimbly vaulting over a grill of domelike, hot coals and completely devastating Nathaniel's side of the argument in his own mind's eye, over what Witherspoon saw and didn't see in the skies; then giving Nathaniel the side-angle-side, one-butt shuffle to boot, like 
old Butterbeans at the Royale Theatre, signifying with his hipbone at Susie's interference.

But just as Blackball's hipbone snapped wickedly back into place, his trousers dipped to his knees, exposing a set of off-white colored drawers, patched up in a dozen places; yet tattered almost to frills on the fringes of each side, and appearing as dangling, ancient catguts, or the rubber part of a frayed corset. Nathaniel rolled in the dirt with laughter, and howled, "Blackball, if you broke wind in those Raggedy-Ann drawers, you'd probably fart dust, 'fore I could say Jackie Robinson." Blackball then peppered him with seven agates, from out his bag of marbles.

"Saltie, I sure hope that witch's off-the-wall skin is in better shape than your see-through drawers; you need to stitch a garter belt to your belly button and pitch it over your pants. Ain't youall ever heard of Ben Franklin, Houdini, Dr. Carver, or Ivory Joe Hunter?"

"Fool, everybody knows you and Stalebread Winters don't know the difference 'tween a jockey strap and a sanitary belt-'cause that thing 'tween your drawers is a caterpillar in a cocoon, ain't spinning."

"... Saltie-Dog ... you just let the butterfly out the barn. You think when a woman has her period ... you so dumb... and off the wall that she changes her skin ... 'cause you think her blood boils over ... you don't know dousing from douching."

"I know 'nough to know when your mama's on the rag... Your half-white daddy's painting the town red."

Now the youths were hot in each other's faces; setting their lips around the best and the worst blue-streaked, purple-charged curses of mother-goosing and father-flailing. Finally, a cop car rolled by, marked 1066, and they saw the notorious Two-Gun Westly inside-a World War II, shell-shocked Negro policeman, known to kick ass, then take names, and never ask questions. And suddenly their young arms, raised in defiant, measured dukeing-on-down warfare a second earlier, now came encircled around each other's shoulders, as two ancient warriors returned from months in fierce combat with the enemy and desperately, affectionately, even profoundly glad to see each other (even though they fought daily in peacetime) now that the armistice had occurred and the beloved lovers, stolen from each warrior's camp, were now returned, with no question over the loss of the virgin girls' honor ... Old soldiers, arm-in-arm, ace-a-boon-coons-like, those World War II vets who so often collected at Williemain's Barbershop, retelling helmet-lines of old combat stories, cast in steel pots of fabulous lies on Saturdays, that 
Nathaniel heard as he shined shoes in the corner, and Blackball heard, when he delivered the Evening News.

As Two-Gun Westly tooled his cop car on down the avenue, Blackball started up again in rhythm with the one-butt shuffle: ". . . But now that witch spins up in her hot old skin-her skin all the same-it fits her just fine, like them hot-tailed dancers prancing 'bout the stage of the Royale-show-outhouse!"

"Wait a hot minute, showboating Saltie-Dog; fits her just fine-as torrid as that Tabasco is-I can't suit up to wear that scarecrow's patched-up, sizzling long suit; to say nothing of your patched-over tales. Next you gonna tell me that witch thinks she's having her periodearly, 'fore it's too late."

"Batty-Natty, there you go hammering a head on a tail-thinking it's a nail."

"... Anyway, how can a witch see her blood when she's invisible?"

"Tar and turpentine, Spoons... Spewed-up Tar Baby ain't disputed that."

"I'm talking 'bout blood, Blackball."

"You trying to deny a witch a cunt, half past midnight, colored boy ... How come you think witches keeps on coming, even when they flying. . . ? You trying to say witch's ain't bloodthirsty? Even when the moon's blood-bathed? You think you the onlyest one with a bloodstream, just 'cause your face flushes blood-red in the dark?"

“... That's right, Blackball ... go on and try to put me behind your eight ball... Tell me anything. She's the last of the red-hot mammas ... I'm Nicodemus, playing Brer Rabbit, you're John the Baptist, the Tar Baby, and that witch's Mary Magdalene, washed down in silver white vanishing cream," Nathaniel quailed, doing an exact imitation of Maxwell Saltport's most furious tenor climbing to the top branches of a soprano saxophone squall.

Looking into the Heavens, with his fingers waving to the skies, Blackball declared: "Poker-hot ... Altar-boy Catholic stewball ... Like Miss Satan's pitchforking five-finger-pitching toothpicks, you mean; even though she moving like she got the seven-year itch, the Saint Vitus dance and Tabasco-dripping snakes of cutting fire, her body like lice-cified warts of iodine, setting off Roman candles, inside of long johns, inside of painted-on Levis, on the Fourth of July-and she can't hardly stop itching for dancing, or dancing for scratching ... Talking 'bout her backfield fleecing her motion, while the bowlegged water boy's making 
an end run, with her bedbugs, chiggers, and water bugs ... But Nathaniel, man, she is enjoying it to the backbone-strut of her split tail! Spoons-to the nub of her cold-hearted, nutting-on-down bathhouse broth! Why she's almost nutting out of this world-backwards.'"

"Enjoying herself? Broth? Broth-as-blue-blood, blood-brother? Bullshit-like pooting-warmed-over potatoes au gratin ... Unless she's spinning up a nude dance, flinging out of that old skin, nobody but her warlock can see...Him, and you, Blackball-Saltie-Dog... And ole Miss Witch, her highness, jigging and screwing, screeching and pitching into some new off-the-wall skin-unless she's thinking 'bout laying her old man some new-time hot-tail skin, all the while and screwing in slow motion, by the numbers, out of sight. But Saltie, talking 'bout being fleeced by Two-Gun Westly and skinned alive, by a hog butcher!" And then he thought of the men telling tall tales of "doing it" standing up, in their truth-skinning lies at Williemain's Barbershop.

And Nathaniel thought of Mrs. Lillian Hopkins, who was always drooping forth pregnant; who hung her wig of Indian hair (like "a quartered mink") on the old golden dinted bedpost; "a newly enfranchised skull," his father said. Uncle V.I. DuPont said, "That's why her brains are rusty." The bedpost looked as a battered, doleful trombone to Nathaniel. But Uncle Uncle Ulysses Hampton remarked, "That Indian wig moves Hopkins to groove with his slide trombone."

Blackball was already fanning himself elaborately with a mock motion of his flapping hands as overheated church ladies. He dabbed at his face with a huge, tattered red and white handkerchief.

"Natural nutting bee-hind. She might have to change skin in a split second, 'cause like Two-Gun Westly she's always on call—or change her snakeskin drawers covered over with tar and turpentine. You and I can't see. See what I mean when I say she's got to go through with the laying on that of that skin or vanish trying?"

"Oh, you don't mean patched-up like your drawers-but spun over as dyed-in-the-wool, see-through veils, that wiggle like a snake's skin. That you can see through but can't see inside of ... on either side? Even though you got eyes in the back of your head ... back there where the imagination flourishes like Buckingham Fountain?"

“... You can't see for looking, Spoons... See this Tabasco sauce anointing oil now gets to percolating up her mind; giving the witch another idea, Momma says of how she can torment others-meaning me, and 'specially you-meantime she pure 'nough enjoys the grinding music of hot aggravation." 
"Well, I didn't expect she'd be doing a fox-trot on the killing ground and rolling the rocks from out of her bed," Nathaniel howled and thought of the balding Sergeant Ulysses Hampton singing in that deep southern-fried-batter voice-down at Williemain's Barbershop-with his personally cured, home-brewed hot sauce dripping and trickling on down his chin, trying to roll out Prysock into Eckstine: 'Rock me baby, till my lungs can't get no air. Roll me Momma, till I looses all my hair.'

“... No Nathaniel, beyond a shadow of a doubt, that bitch is the Devil's kept woman, with rocks in her bedspring ... and her ass moving like two bald-headed babies beneath a bedspread rocking to glory on a rubber sheet."

"What broth of learning you been drinking from, Blackball?"

"... Momma says she now knows all about witches, since she got saved. Mister Nattie High-Pockets, Mamma's stone dead in the market set against dancing... She says for the very Heavens declare the glory of Gawd."

"... Talking 'bout the backbone disconnected at the hipbone ... Or I should say, the skullbone disconnected at the neckbone. Now hear the word of the Lord. Why I declare on Thursday," Nathaniel heard himself saying, and his mind drifted away-sounding like Aunt Hattie Breedlove Wordlaw; her phrase rippled upwards through him. Or Uncle Hampton saying: "Just give me a pig's foot and a bottle of beer-then, Man, I'll bottle up and rail on away from here, like the Super Chief." But Nathaniel was also thinking: Blackball, too bad your Momma stopped dancing 'cause I hear tell she had some most wicked midnight notions and meanly righteous backbone, backfield motions, or so Uncle Hampton declared.

But Blackball was saying: "Spoons, now that she is in her skin, dancing, hopping, sousing, sashaying about. Coming to reknow her true self, which was a real hot Momma once upon a time-that's exactly when you will swoop down from the very housetop-when the witch says, 'broth'-like a jackrabbit; then discover who she really is. Quarter her to pieces like Momma told Great-Grandma Julie-Jewel she useda think 'bout doing before she got saved; when she was working days for that mean old bloodless witch Miss Eliza 'Lock-Bowels' Booker; it come to pass time to chop up the beets; she would see them as old prune-faced Booker's body and the beet juice come to be the broth of that woman's best blood and Great-Grandma Julie-Jewel says how that solely reminds her of old slavery time when she put a hand on old whipping Master 
as he's stropping blood from her old man in the barn ... How when old Master gets most tried of whooping, a slave-messenger, named Elijah comes in with a note from ole Miss Natural pleading with him to stop lashing down that nigger slave 'cause she's about to bleed to death with every strap and it's almost too late now 'cause old Master done commenced to burning salt into the lash wounds of Great Grandpa now old Master outruns the slave-messenger getting back to the house dropping salt all over the ground in his tracks, but when he comes in the house to his torment is his wife, bleeding from head to toe and old Master takes to howling wild out of his mind starts to tearing out his eyes with the hold-up belt from old mistress' bloody gown; just as he starts, her silk gown falls about her skeleton knees; her nakedness is void of skin. Everyplace he moves drops a peck of salt onto the earth. At last salt cuts a six-by-six-foot deep grave. He topples into it. Then Julie-Jewel starts to singing: 'Nobody Knows the Trouble I've Seen.'

"That skin will be like an electrified straightjacket on a statue, worn-out by the time she goes stone cold," Nathaniel said, trying to return Blackball to reality and himself to his supreme vision, yet thinking about Jamestown saying, 'Carving knife for white mice ain't no switchblade attall.' Uncle Ulysses who used to blaspheme by dousing Tabasco sauce on Aunt Genevieve's Creole Gumbo.

"Statue? See there you go now, Spoons, thinking like a Catholic-been drinking that holy wine at Mass. Everybody knows it ain't nothing but pure-d homogenized elderberry wine-it's overheated your circuitsGreat-Grandma Julie-Jewel says 'cause you New Orleans colored Catholics, who also passes for Creole, always praying up to them statues to cop you a sweet plea to Almighty God, like them old-time Africans going from one God to the next god-to-the-highest, with cutout masks over they faces-like you all going from house to house begging poor folks for the gold out their wisdom teeth so that the dress-wearing Pope can sheen 'round in a Golden Chariot, with the Virgin Mary on his arm-like Father Divine with his snow-white Virgin bride in a fishtailed Caddy - when ain't but the one God! You better declare to Him Proper on Sunday, 'stead of Thursday....

“... Spoons, no wonder you seeing visions-when you ain't even heard tell of being double-sighted. Re-echoing them same prayers over and over again like you seen the Wolf-Man. Your teeth chattering, as the rattling jawbone of the skeleton in the biology lab at school, when somebody leaves the window open; gate to the hamster cage unlocked; 
you take to stuttering over again, like the gone-loco hamster running back one, then forth the other way in reverse English of the limb of the apple tree outside the lab window. When somebody's pranked him out with a gage of marijuana. My Grandmother Julie-Jewel says that's how come you colored Catholics in a straightjacket, 'cause the Devil done told you to freeze-but like a statue, worshipping itself and falling off into the water-unsaved "with all you Sunday best on." "'

"Saltie, you thinking about Elderess Lucy Longhorne, high on elderberry wine and spouting out over the radio... 'if you all don't send me your belongings, even unto your old drawers, for the poor, a worser man than Hitler gonna get you.' But you believe those Hot clothes are going to hug and freeze to the witch's booty-Hell, hot sauce ain't glue but it sure flies like Warm-Gravey's fingers over the piano scales."

"Who said they 'Hot'? That witch does her own stone-cold stealing; her own hot-breathing laundry: with Rinso-white, a shot glass of bleach, three shakes of cornstarch and three drips of pure coal oil, out of an eyedropper for measurements ... Oh, you mean like $H-O-T$ Ice? Man, you must had a hot dream woke up with a gluey hand on a wet sheet full of cold come."

"Hugging Hot-wax-Max-you know what I mean. Don't try to put me onto a bag of pigeon-drop hot-ice and school me-it's a sack of stone heart-shaped diamonds; then tell me to keep on trucking with an armload and old Two-Gun Westly steady waiting for me behind the corner. Besides hot-ice smokes like Willie 'Bad-Air' Threshold's breathing-like a bean-bursting bloom fart down on that hooked-up swing of his in the wintertime, where he hangs out, as he gets over his hangover, hanging on ... and nodding away."

"Cool down, Poppa, 'fore you flip your wig. Snug as bedbug weaving in long-woolies, trying to clench its way home, backwards; more fitting than Tar Baby's skinny-skin goose-greased in turpentine ... Man, that Tabasco sauce start to circulating 'bout like coming and going motion of blood to the heart," and here Blackball, who was at the head of his biology class, drew a sketchy diagram in the earth with his wiggling big toe protruding from the crackling gym shoe of two intersecting figures to show the currents of blood flow. But Nathaniel recalled how Stalebread always said: "Now excuse my right hand take my left hand it's closest to my heart."

"Spoons, that skin's like a limp membrane; but when that hot sauce starts to shooting through her... circulation's gonna dip; rise and 
explode-like one of them dope fiends mainlined to Hell in a shoot-'emup crazy-fit, high on horse, strapped to a helium balloon!"

"How? If she's tormented in the brain and itching like she's bloodthirsty-with her invisible witch's nails bloody to the deadly quickfrom her anklebone to her hipbone to her skullbone and her bottom's moving like she's grooving and brewing up a broth with her buns grinding like grape-mashers."

Maxwell gave Nathaniel his cross-eyed look-something akin to a parody on the intersecting figure eights-all of which helped support Saltport's claim of being double-sighted. He was in fact, double-jointed. "Hush your mouth-Chile-now you strictly talking 'bout Sitting In It; as my Momma useda say when she got happy, 'fore she got saved; pure joyous for Jesus. Be-cause, Spoons, by that old Witch dancing, moving, fretting, flouncing in such new sashaying ways, she be turning ... like she's trimming-on-down ... Shooting that red-hot Tabasco sauce into a cold-blooded reality ... It'll be flying into her system and veins like the Colorado rapids in those Hopalong Cassidy shoot 'em ups at the Joe Louis picture show. But, Spoons: Mainlined to a chilly! Quicker than the time between turning the light off... Before it's getting dark in the room ... that old radio man says, 'Lights Out, everyone.' Then you lights out for some parts of cover ... That's why we shit you, Spoony-Moony, got to swoop down there swifter than Jack-the-Rabbit, or quicker than Jackie Robinson could steal 'CoolPoppa' Bell's lightning-fast soul out of a Gingerbread man's shortenin', and she commences to get more cold-blooded than a frostbite apple; then a worser man than Hitler'll get us all: her Mack-man Warlock! He knows the difference between a fart, a clap of thunder or crack of dawn! That's what I thought you meant, like Hot-Ice ... Come up smoking with life from the foggy bottom!" And then Blackball did the Hambone, wailing:

Hambone, Hambone, where's your wife

Down in the cellar shooting dice,

She shot six, I shot four, come-on

Baby, let's shoot some more.

Nathaniel Witherspoon felt like Harpo Marx flicking the lemon pie out of his eyes, but discovering the flicks of the meringue remained in his long eyelashes. 
"Bullshit. You're the one whose gone to Nut City in a black and blue straightjacket and a wheelbarrel full of vines turned to split-off threads that even Rumpelsticksin couldn't hardly turn to gold...."

"... Spoons, it'll be greater than an eclipse of the moon."

"... Blackball, you would dress a corpse in long johns, cape and a black top hat, done up in swan's feathers; and a rabbit's foot 'round her wrist, and then bring her to life with a flick of your broomstick for a bloody wand, in the shape of a witch, riding on the broomstick."

... Spoons, Tabasco hotter than any hot-ice ... Can't cool her body broth ... or hot-blooded Bea's tail, when that bad sauce shoots through that hoe's ... circulation ... Turn her broomstick to a pole vault."

But Nathaniel thought of his Aunt Genevieve saying: "If it wasn't for bad blood-wouldn't be no good blood attall," as she grunted and ground her way-impossibly so-into her girdle, and her parrot, Mister Tenderloin, shouted: Amen, Sister Goodbody, Amen, which proved for Nathaniel at least one reason why it was so hard for the body of a camel to enter the eye of a needle, or so Uncle Ulysses had said. Then Nathaniel thought of Uncle Jerry, who died of syphilis, and had scratched his body down to a nutshell so that it looked like the crimson patches slabbed upon a scarecrow; and Uncle Richard who suffered from twelve different kinds of food allergies, a lobster to a peanut, that made him scratch from sunup to sundown, head to tail to toe and the penniless Willie 'Bad-Air' Threshold whose left hand itched all the time and how Aunt Genevieve said, "If he ever washed his hands they'd turn gold to green." But Aunt DuDora who went out near there where he lived in the swing in the wintertime when she tossed bread crumbs to the pigeons... and the rumor how he sold from the pigeon these bread crumbs.

"... Witherspoon, you got to come down from the top of that house. Your mind's off on cloud 369, spying statues in rainbows through a skylight of a spyglass ... Come down from where you off tiptoeing in space-looking a beanstalk, with an axe in both your hands and DO GOD'S BUSINESS!" pointing to the Heavens; his eyes rolled 'otherworldly.' The spring sun glinting in his eyes as he tried to shield his vision with his long dark hands, and Nathaniel thought of the pictures of Jack Johnson in Williemain's Barbershop guarding his eyes from the sun while seated on the canvas in Havana. Brer Rabbit inside the soul of Tar Baby. Sam Langford was called the Boston 'Tar Baby'-but had called his six-inch crush of a punch, "The Mary-Ann." 
Then Nathaniel found himself back down on the ground, this time laughing and howling and thinking his whole body would crack up and disconnect at the ribcage, and then fly off in four different directions. And the torso would become connected to the lower quarters of a goat ... Well, you had to be stealthy at climbing and clinging on those slippery hills and mountains to go along with Blackball's hot slippery bullshit, he thought. A steeplejack to play his steeplechase jackass; bottomed out to his bottomly bumpkin. And Nathaniel thought of the story they had been reading in school of Ulysses and how in escaping the Cyclops he had hooked himself beneath the belly of the ram, in order to flee safely from the cave. And how Ulysses had held on for dear life.

But Nathaniel thought that old Ulysses had enjoyed the trick of the ride underneath all the time, even as the Cyclops had one eye and Blackball continually made his eyes appear as four, as if he were about to riff signifying into the dozens, on a trumpet like Satchmo. Blackball and the Cyclops loved wine but Nathaniel was becoming a natural fool for those Indian cigars, behind old man Butler's mansion, that made him feel so powerful, and nimble-headed high: who said Catholics didn't know how to get happy-without wine? But Stalebread seemed to have a monkey on his back. All of which forced Nathaniel to think of the joke about the buzzard and the monkey that the merry old soul Nat King Cole sang about:

The buzzard took the monkey for a ride in the air.

The monkey thought that everything was on the square.

The buzzard tried to throw the monkey off his back.

The monkey grabbed his neck and said,

Now listen Jack,

Straighten up and fly right,

Straighten up and stay right,

Straighten up and fly right,

Cool down, Poppa, don't you blow your top.

But he liked it best of all when the guys did their own jawbone riffs on the signifying monkey and the lion, sometimes using a duo of spoons, other times using a tambourine, other times, tissue and comb.

Intoxicated Uncle Ulysses, with a straw in his pint bottle of scotch, sucking up those blood-boiling last drops, would say: "Jack Horner, here 
I come Coffin's corner ... so kick it." And the bottle would up at a slant like a punter's leg and foot rising to boot a football into the air; and all eyes would climb upward as cheerleaders following a football as his bottle at his lips, went up, his head slanting to a tilt. And then he'd say: "What the vulgar call sucking the monkey/Has much less effect on a man when he's funky." Now Nathaniel felt his own soul's biceps ripple, twinkle, pithy with overreach.

"Blackball, how come we got to use axes? Anyway, I didn't have no axe to grind against your invisible witch. What kind of men are we? What of the power almighty of our own hands? You can do eighteen pull-ups on the chinning bar and I can throw the twelve-inch softball half the length of a football stadium. And didn't we find our way home in the dark from the forest preserves with nothing but old man Butler's flashlight, and Uncle Ulysses' compass, when that old bald-headed Boy Scout Master, Mister Gene Darling tossed the twelve of us out of the truck in the night to see what boys were truly made of in the dark. You remember, Maxwell! Only you and I survived, those other slim jims got lost inside their backpacks.

"And Hell-fire, I know how Samson rent a lion like it was a skinned kid, with nothing but his hands, and then the swarm of bees and honey left in the foul carcass of the evil-hearted lion-he was so bad-and he took the honey out and gave it to his parents to eat like ambrosia and Great-Momma Sweetie Reed told me about that and she sure 'nough is no Catholic like you always turning all of my blood into being, when you stand my family on top of its head and try to shoot them all through the signifying grease.

"But now, Blackball, if he could do that to a lion he never saw before, how come the two of us can't handle a witch with our hands, that no one has be-held in the fierce light of day?"

"Yeah, Samson, he was bad all right but Miss Boss Delilah sure told him to freeze, on full. She pure night-timed bossed his come...."

"Delilah could have a golden chariot-chair at Williemain's Barbershop?"

"Miss Delilah sure sure knew how to put a golden razor to his glorified naps ... But now did your Great-Momma Sweetie Reed tell you-did she school you that Miss Delilah was a lady-lioness in the dark, with a sugar-foot strut, pure elgin in her grind; maple molasses in her bee-hind-but Spoons, since your brains outfitted up a mosquito's ass make him fly sideways, you couldn't know what I mean 'bout no 
spewing Tabasco sauce smoking down her backbone ... 'Cause grandmamas can give you a heap of wisdom; but they ain't tell you dooleysquat 'bout no hot tail-time, in the old town tonight."

"Blackbone, I'll crack that witch's vanishing back with a jawbone and see if she howls; or if that's your loud mouth on tour, bad-air screaming like The Hawk full of hailstones and only breathing her into being, dangerous as steam off hot-ice, as a warning signal ... Only hot-lipping her into the shape of the Holy Ghost... And maybe I'll use your jawbone to boot, to do your business, it's so well exercised, Saltie-Dog."

"... Mowed his laundried, processed mop ... Read his natural balmpalm ... Sure know Samson wish he'd taken that sugar-stanky-spook in hand. 'Sides that witch is more man than Samson-and more freakish than old man Gene Darling 'cause she can turn to a warlock at Dawn; my Momma says how she learned from your pure Auntie, Miss Genevieve, who knows more 'bout devilment than Delilah's drawers, 'cause she's a Roman candle Catholic; a yallar-jaundiced conjurer lady, a skin-stripping hoe, and a Ma-Dam, and she's married to a German po-lice dog white man, who makes beer in his basement, that would kill off a pig after a tablespoon... That makes her Mrs. Hale-Heil Hitler and she's pure sent up from New Orleans on a crimson broomstick, with a pitchfork for a face."

"Look here, B.O. Plenty ... Blackball, you glowworm, you're a warlock and your Mother went to church after she had a shit hemorrhage at a Revival Meeting; got high on her broomstick ... after she got low down, she got up, thought she was struck down with religion ... Come to find out she didn't have nothing but a common cold."

They wrestled on the ground for a long count of seven minutes (each with the corner of his eye cocked for the light of Two-Gun Westly's beaming police-car light) letting furious charges and jabs fly. Blackball put a hammerlock on Nathaniel and made him "confess" his sins and with his free hand started to choke his friend, and made him "confess" and "cough up" his "sins in the way you confessing, statue-worshipping Catholics stool-pigeon on yourself to Father" and then "five Our Fathers" was set for the price of freedom but making Nathaniel whisper "Father" instead of "Uncle."

But then Nathaniel tripped him up and got Maxwell with a step-over toe hold and made Blackball chart his anatomy bones backwardsheelbone to skullbone, three times... Maxwell kicked his way out of this hold; by first of all slitting his highly available toenail into 
Nathaniel's heel; then Nathaniel tried a Cobra Twist, like the matman Cyclone Anaya employed (a wrestler's hold, which Uncle Ulysses Hampton said seemed like someone was trying to do it to you backwards); and Blackball slipped the poorly executed wrestler's hold; he countered with an attempt at a version of Chief Don Eagle's Indian Death-lock, Stalebread Winter's favorite hold. They huffed and they puffed and then stood frozen and pondering each other, like two spent young lions, finally Nathaniel said: "I know a new patch where we can go and find some Indian cigars... Back of old Butler's backyard, next to his corn patch." But Blackball gave his Groucho Marx, cross-eyed look, as if the thought made him high already. The youths swooped away, making eagle-flapping motions with their arms.

Now in Butler's sunken backyard-loaded with fruits, vegetables, and all kinds of trees, strange plants, and weird flowers-as they puffed away on the long, double-jointed, string-bean-shaped, green Indian cigars, with the parodied effeteness of Lords and Counts, Nathaniel declared: "But how will we discover who she is if we don't know whose house we are breaking and entering? How will we know the right house, in the beginning? And suppose it's dark, inside and outside? So what do we do, get a seeing-eyed dog? Aladdin's Lamp? And if I look anything like Sky King, in your eyes, then you can borrow my spyglass, Captain Midnight, and call me Batman!"

"... See Momma says by hugging and holding onto this dream, or notion, like the one you think you seen, all day and each and everywhere you go, no matter how that dream, or peculiar vision tries to get away from you, or how much folks-'specially teachers-says you are just daydreaming, even if you have to stay in the library till sun sets in the summer, then miss Sky King, Terry-in-the-Pirates; Tennessee Jed in the winter-your mind oughta be glued to the dream, but on top of it, you got to ride that witch's mind waxed upside down; stayed on it-oughta be easy for you, Nathaniel; the way the rabbit was plastered upsides Tar Baby 'cause you so arrogant in your deeper nature ... 'cause you can't go to no Mass, during this particular period.

"See that's why I steady keep on telling you to just plain freeze on hold; hold on to that spot-like you got a thermometer 'neath your tongue while your temperature is skying to 105 , in the shade; your chest bathed in turpentine, hotter than Tabasco sauce. But now, Nathaniel Turner Witherspoon, I also schooled you not to fall in love with freeze. This ain't no Honey-Suckle-Bea-Treadwell slow dance on the killing 
ground. 'Sides ('cause you don't learn to listen to nothing I tries to teach) I said that witch sat her jack-o'-lantern on the table; her white witch's rickety broom-like a pale horse-in the corner and it will be all glowing up pure in the darkness for you to see enough of her by.

"Don't let Stalebread hoodwink you, 'bout gouging out her eyes, 'cause they're truly yo-yo's and snap right back into place... not running egg yolks, that's what he thinks."

But who could call upon Stalebread for anything other than schoolwork and information about his love for the Indian wrestler. For so in love was Stalebread Winters with Chief Don Eagle, that he had his own hair cut at Williemain's in a Quo Vadis/Don Eagle hairstyle that made his head appear as an unnatural, quartered cantaloupe skin with a furry wool do, capped down to the skullbone; a strung-up half-moon shape. Blackball had learned the Indian Death-lock from Stalebread Winters, who saw the wrestler's hold fixed as a kind of geometrical shape, in his mind's eye.

Nathaniel started to retort, "The Church is your mother's briar patch," but rubbing his sore arm from Maxwell's hammerlock, he simply replied: "You mean with no relief line in sight. Like you caught up in Chief Don Eagle's Death-lock; ref's eyes going 'round in his head; ref's eyes yo-yoing, like Stalebread's eyes; his hands in motion, but never touching the mat to count.

"But I thought I was trying to get free of the witch, not hitched to the bee-hind of her backbone, bucking her down for the night, with the Cobra Twist, after hours. My second mind tells me I ought to tie a lock of hair to the witch's hide to keep her ... chasted!"

"Spoony-Moony, who ever heard of anybody chastening a witch ... Your second mind's too slow for this high-wire action."

"And that makes me think of something else too. Suppose when I$w e$, 'cause you, Sir Saltie-Dog, sure as hell-fire gonna be there with me-when the nut-cutting goes down and I don't mean the killing ground.

"We ought to climb to the rooftop all right, but bore little dolly-eyed holes for seeing-eye sockets, into her roof so we can spy on what that witch is doing, then when the witch gets in the right spot, and a grinding her way into her skin, pour boiling-hot water down through those eyeholes-not drippping Hot-Ice, Saltie, because suppose if we do just swoop on down and her old man Warlock, turns out to be her Sugar-Stomping Daddy Warbucks, comes in drops his pants to his 
drawers, like you just did-and gets ready for the function at the junction-as you and I come floating down from the rooftop, we'd be in a whole mess of trouble-and man that Warlock knows how to put on a real Death-lock, he ain't sloppy, Main-Brother-man!"

"You must be thinking he's related by kin to Regal Pettibone ... You sure getting caught up in my action/Jackson. Warlock'll be souse-doused on Heavenly Hill. But if he ain't, you better turn that axe to a gitty-yup horsey; dolly the fuck on out of there-like a ghost chased by a spasm-shot of greased lightning -if you come down while, catch him coming while he's doing the 'Cobra Twist' up his witch's background... Or maybe we'll just have to remember my great-grandmama's conjure to fling him away-just carry a tobacco pouch of cowshit, white folks' hair, red-hot peppers (you already got the Tabasco sauce). Or maybe we'll just have to depend on Thursday's child-that's the night I hear tell that witch's warlock goes crapshooting with Satan downtown-down on both knees, till the hour of the wolf."

"Well, all I know is wings you ain't got on your back you better get in your feet, as Great-Momma Sweetie Reed useda say she heard up from the old folks back down in the old country. But suppose that warlock turns out to be old man Butler, himself?"

"Then we'll take a page from your Penworthy; bore eyeholes in the roof, fly through those holes, turn Butler into a Bull, mount him. You in the front-spend the whole night riding, lashing him, like we was sure 'nough rodeo-rough riders."

"Old man Butler is all bull anyway. Hey, how you know it's Butler?"

"... Spoons, if you went to Mass before we got our plan unveiled, you'd have to confess. Ruin everything. 'Cause them old priests are warlocks disguised in black dresses ... But what we might could do is to flick mustard seeds through them eyeball-dolly holes you gonna bore in the rooftop-she'll be so busy counting them-thinking they gold nuggets, shimmering all over her ... whilst she's grinding her way in her skin, and sho-shoing her warlock to bed with the other hand, she won't have time to spot you haunting-on-down."

"Well, Max, I sure as hell want to know who she is 'fore I ride down her, without mounting her I mean ... and him too, doused as he can be on Heavenly Hill... She might have more spots on her than the tattooed lady in the circus sideshow ... splattered head to toe."

“... But then see, Spoons, some night you'll get it all straightened out. It'll all come back even unto you who she is, or was in her other 
life, in the recollection part of your nap-cap, here, just let me point it out to you. It'll start off in your heel bone, like an itch, then transfer to your hipbone, then suddenly fly to your pointed skullbone, or your natural knowledge come (where your I.Q. stands on its head) like an air-raid signal in the dark. Now just follow that crooked trail from $A$ to Zig-zag-assed $\mathrm{Z}$. That's the only way to get under her scratching skin: let her ride you completely, as you riding her hobbyhorse, freestyle, body, soul ... Head, shoulders. Toe-jam to asshole to buggers to skullcap that old nap-cap. But freeze, like hot-ice. Start singing, as old Billy Daniels, 'That Old Black Magic that you weaved so well, those icy fingers up and down my spine ... and I got you under my skin,' puffing out angel's hair but mixing up a witch's brew in your mind-higher than a man humping on Heavenly Hill.

"I'm telling you, Natty, boy; don't you even dare change drawers, socks, cap, woolies. Even let her snatch a blue knot in you. Then that witch's first habits will become your natural, percolating second nature, just as she is learning yours and then you'll be wearing a new skin; that'll be your long suit, 'cause that's when you'll upset her circuits-"

"I guess ... so with that red-hot Tabasco sauce turning to fire-it'll burn out that wire's in charge of her battery-brain -"

"Naw, boon-man-Spoons... Shooting with reverse English. If that witch gets hateful, spewing, leave her be, or she'll snatch your ass through your nose, into a blue black knot-but still keep hanging on like you got Man-o'-War whirled-a-way, by the harness; you'll get so fast to her ass, she'll be asking you to tell her the way home. But don't let her flip you like I just did, don't care how she tries you-just be a romping, stomping rodeo-rider, a sea horse and a C-C Rider."

"Wait! I'm to cling to her on her night maneuvers?"

"Yes ... Easy-Rider ... Beyond a shadow of a doubt ... Lights Out, Everyone!" 